\title{
NEUTRON AND GAMMA SPECTRUM ANALYSIS OF KARTINI RESEARCH REACTOR FOR BORON NEUTRON CAPTURE THERAPY (BNCT)
}

\author{
Rosilatul Zailani ${ }^{1 *}$, Gani Priambodo ${ }^{2}$, Yohannes Sardjono ${ }^{3}$ \\ ${ }^{1}$ Department of Physics, Universitas Negeri Semarang, Gunung Pati, Semarang, Central Java 50229 \\ ${ }^{2}$ Department of Physics, Gadjah Mada University, Sekip Utara, Bulaksumur, Mlati, Yogyakarta 55281 \\ ${ }^{3}$ Centre for Accelerator Science and Technology, National Nuclear Energy Agency, Yogyakarta 55281 \\ Diterima editor: 15 Januari 2018 \\ Diperbaiki: 12 Maret 2018 \\ Disetujui untuk publikasi: 13 Maret 2018
}

\begin{abstract}
NEUTRON AND GAMMA SPECTRUM ANALYSIS OF KARTINI RESEARCH REACTOR FOR BORON NEUTRON CAPTURE THERAPY (BNCT). MCNPX was used to design a threedimensional model of Kartini Research Reactor (KRR) as a neutron source and performed criticality calculation. The criticality calculation of the reactor aims to obtain the neutron and gamma spectrum by simulating the fission reaction inside the reactor core. Total source histories were 105 per cycle, when the number of cycle for criticality calcutation was 1000 cycles with 60 skipped cycles. The reactor criticality according to the simulation result is $1.00179 \pm 0.00007$. The total neutron flux on ring $\mathrm{A}, \mathrm{B}, \mathrm{C}, \mathrm{D}, \mathrm{E}$ and $\mathrm{F}$ inside the reactor core are respectively $6.553 \times 10^{11} \mathrm{n} / \mathrm{cm}^{2} \mathrm{~s}, 4.53 \times 10^{12} \mathrm{n} / \mathrm{cm}^{2} \mathrm{~s}, 4.167 \times 10^{12} \mathrm{n} / \mathrm{cm}^{2} \mathrm{~s}$, $3.751 \times 10^{12} \mathrm{n} / \mathrm{cm}^{2} \mathrm{~s}, 2.914 \times 10^{12} \mathrm{n} / \mathrm{cm}^{2} \mathrm{~s}$ and $3.107 \times 10^{12} \mathrm{n} / \mathrm{cm}^{2} \mathrm{~s}$. The total gamma flux is $6.956 \times 10^{11}$ particles $/ \mathrm{cm}^{2} \mathrm{~s}, \quad 4.838 \times 10^{12}$ particles $/ \mathrm{cm}^{2} \mathrm{~s}, \quad 4.398 \times 10^{12}$ particles $/ \mathrm{cm}^{2} \mathrm{~s}, \quad 3.962 \times 10^{12}$ particles $/ \mathrm{cm}^{2} \mathrm{~s}$, $2.953 \times 10^{12}$ particles $/ \mathrm{cm}^{2} \mathrm{~s}$ and $2.013 \times 10^{12}$ particles $/ \mathrm{cm}^{2} \mathrm{~s}$, respectively for each ring. Thermal neutron fluxes recorded on the base of radial piercing beamport were $4.678 \times 10^{10} \mathrm{n} / \mathrm{cm}^{2} \mathrm{~s}$, with the epithermal neutron flux of $5.37 \times 10^{9} \mathrm{n} / \mathrm{cm}^{2} \mathrm{~s}$ and fast neutron flux of $4.17 \times 10^{10} \mathrm{n} / \mathrm{cm}^{2} \mathrm{~s}$. The gamma flux on that side reaches $4.22 \times 10^{12}$ particles $/ \mathrm{cm}^{2} \mathrm{~s}$. On the $92-\mathrm{cm}$-ranges from the base inside radial piercing beamport, both neutron and gamma flux decrease up to $5.11 \times 10^{8} \mathrm{n} / \mathrm{cm} 2 \mathrm{~s}$ for thermal neutron flux, $4.598 \times 10^{6} \mathrm{n} / \mathrm{cm}^{2} \mathrm{~s}$ for epithermal neutron flux, $2.55 \times 10^{7} \mathrm{n} / \mathrm{cm}^{2} \mathrm{~s}$ for fast neutron flux and $8.214 \times 10^{10}$ particles $/ \mathrm{cm}^{2} \mathrm{~s}$ for gamma flux. In conclusion, the spectrum yield from this study can be use to define the source spectrum of the simulations and optimations prior to BNCT pre-clinical trial (in vivo/in vitro test) use KRR radial piercing beamport.
\end{abstract}

Keywords: BNCT, radial piercing beamport, Kartini Research Reactor, neutron spectrum, gamma spectrum

\begin{abstract}
ABSTRAK
ANALISIS SPEKTRUM NEUTRON DAN GAMMA UNTUK BORON NEUTRON CAPTURE THERAPY (BNCT) DI REAKTOR KARTINI. MCNPX telah digunakan untuk memodelkan bentuk 3 dimensi dari Reaktor Kartini sebagai sumber neutron dan melakukan perhitungan kekritisan. Perhitungan kekritisan reaktor bertujuan untuk mendapatkan spektrum neutron dan gamma dengan mensimulasikan reaksi fisi yang terjadi di dalam inti reaktor. Jumlah source histories adalah $10^{5}$ per iterasi, dimana banyaknya iterasi yang dilakukan dalam perhitungan kritikalisasi adalah 1000 iterasi dengan jumlah iterasi yang dilewatkan adalah 60 iterasi. Nilai kekritisan reaktor sesuai dengan hasil simulasi adalah 1,00179 $\pm 0,00007$. Fluks neutron total pada ring A, B, C, D, E and F di dalam inti reaktor masing-masing adalah $6,553 \times 10^{11} \mathrm{n} / \mathrm{cm}^{2} s, 4,53 \times 10^{12} \mathrm{n} / \mathrm{cm}^{2} \mathrm{~s}, 4,167 \times 10^{12} \mathrm{n} / \mathrm{cm}^{2} s, 3,751 \times 10^{12} \mathrm{n} / \mathrm{cm}^{2} \mathrm{~s}$, $2,914 \times 10^{12} \mathrm{n} / \mathrm{cm}^{2} \mathrm{~s}$ and $3,107 \times 10^{12} \mathrm{n} / \mathrm{cm}^{2} \mathrm{~s}$. Total fluks gamma adalah $6,956 \times 10^{11}$ partikel/ $/ \mathrm{cm}^{2} \mathrm{~s}$, $4,838 \times 10^{12}$ partikel $/ \mathrm{cm}^{2}$ s, 4,398 $\times 10^{12}$ partikel $/ \mathrm{cm}^{2} \mathrm{~s}, 3,962 \times 10^{12}$ partikel $/ \mathrm{cm}^{2} \mathrm{~s}, 2,953 \times 10^{12}$ partikel $/ \mathrm{cm}^{2} \mathrm{~s}$ dan $2,013 \times 10^{12}$ partikel/ $\mathrm{cm}^{2}$ s, masing-masing untuk tiap ring. Fluks neutron termal hasil perekaman pada pangkal beamport tembus radial adalah $4,678 \times 10^{10} \mathrm{n} / \mathrm{cm}^{2} \mathrm{~s}$, dengan fluks neutron epitermal sebesar $5,37 \times 10^{9} \mathrm{n} / \mathrm{cm}^{2} \mathrm{~s}$ dan fluks neutron cepat sebesar of $4,17 \times 10^{10} \mathrm{n} / \mathrm{cm}^{2} \mathrm{~s}$. Fluks gamma pada bagian tersebut mencapai $4,22 \times 10^{12}$ partikel/ $\mathrm{cm}^{2}$ s. pada jarak $92 \mathrm{~cm}$ dari pangkal beamport tembus radial, fluks neutron dan gamma turun mencapai $5,11 \times 10^{8} \mathrm{n} / \mathrm{cm}^{2}$ s untuk fluks neutron termal, $4,598 \times 10^{6} \mathrm{n} / \mathrm{cm}^{2}$ s untuk fluks neutron epitermal, $2,55 \times 10^{7} \mathrm{n} / \mathrm{cm}^{2}$ s untuk fluks neutron cepat dan $8,214 \times 10^{10}$ partikel/ $\mathrm{cm}^{2}$ s untuk fluks gamma. Kesimpulannya, spektrum yang dihasilkan pada studi kali ini dapat digunakan untuk mendefinisikan sumber dalam simulasi dan optimasi terutama untuk keperluan uji pre-klinis (uji in vivo/ in vitro) BNCT menggunakan beamport tembus radial Reaktor Kartini.
\end{abstract}

Kata kunci: BNCT, beamport tembus radial, Reaktor Kartini, spektrum neutron, spektrum gamma

DOI: $10.17146 / t d m .2018 .20 .2 .4067$ 


\section{INTRODUCTION}

Boron Neutron Capture Therapy (BNCT) is a nuclear reaction-based cancer therapy in the form of interactions between neutrons with boron compounds that have previously been deposited into cancer cells. BNCT is a single and cell targeting therapy that does not give any effect for another healthy cell. Several countries such as Russia, UK, Italy, Israel, Argentina and Japan have developed BNCT as the modality to kill the cancer cells [1-3]. Many of them choose to develop accelerator-based BNCT using different types of accelerators as neutron source [3], but there are a few that use reactors. Tehran Research Reactor (TRR) [4], TRIGA Mark II research nuclear reactor in the University of Pavia [5] and Kyoto University Research Reactor Institute (KURRI) [6] are among the types of reactors, which have been used for BNCT development. Measurement of free beam neutron spectra at 8 BNCT facilities worldwide has been done for beam energy parameters, which require validation and determination purposes for BNCT [7]. Several beam characteristics produced from that 8 reactors discussed by Auterinen, et al [7] are in accordance with the IAEA regulation for BNCT. However, some other need to be moderated with a suitable moderator to catch the appropriate beam characteristics.

Kartini Research Reactor (KRR), a typical of TRIGA-MARK II reactor, is one of reactor in Indonesia that is operated by PSTA BATAN Yogyakarta which has a maximum power capacity of $250 \mathrm{~kW}$. This research reactor is utilized to conduct education, training and research. KRR uses U235 as a fuel and is capable of producing neutrons. Currently, KRR is operated at $100 \mathrm{~kW}$ power [8]. The KRR has 6 beamports that are directly connected to the reactor core [9]. The beamport served as a beamline to deliver particles which were generated from the chain reaction inside the reactor core to the aperture. The development of BNCT-based cancer therapy methods in Indonesia also aims to utilize the KRR, which will be used as a neutron source for BNCT pre-clinical trials including in vivo/in vitro testing.

Monte Carlo N-Particle Extended (MCNPX) is the last version of MCNP calculation method with a general-purpose, continuous-energy, generalized-geometry, time-independent and coupled neutron/ photon/ electron transport code [5]. Several types of reactor have been designed and the criticality has been calculated using Monte Carlo N-Particle (MCNP) computer code [10-12]. MCNP also has been used for many calculation and simulation for BNCT purposes. In Indonesia, KRR-Based BNCT is being developed. The utilization of MCNP for design, simulation, optimization design of biological shielding and collimator based on KRR neutron source has been done through the simulation of neutron and gamma interaction with many kind of collimator and shielding materials $[8,13,14]$. In addition, study of dosimetry calculation for in vivo test preparation has been done as well [15]. The development of BNCT in Indonesia is currently in the preparation of in vivo/in vitro testing by utilizing the radial piercing beamport, one type of the KRR beamport, as a beam line for neutron and gamma yields from the reactor core [16].

Treatment planning based on calculation for BNCT used KRR as neutron source should be done by design and calculation, as a preliminary study. Calculation will take days due to the total number of simulated particles and the specifications of the computer used. In addition, if the source of modelling is not in accordance with the actual condition, the characteristics of the particles output could be inaccurate. Hiherto, the neutron characteristics which produced from KRR chain reaction served only in three different level of energy (discrete data), such as thermal neutron flux, epithermal neutron flux and fast neutron flux or even served only in form of the total neutron flux yields [15]. These data are less appropriate if it will be used as a reference to describe the neutron source in the simulation code since the available particle characteristics are limited and in the form of discrete data. If the data are used, then it is concerned will affect the calculation results.

The simulation and calculation of particle yields due to the chain reaction inside the KRR core have been performed. This study serves the spectrum data of particle yields which can be used to define the source spectrum for another works related to the KRR-based BNCT. The objective of this study is to obtain the information of both neutron and gamma beam yield from the chain reaction which was simulated inside the reactor core. The particle yields were recorded and calculated both inside the reactor core and inside the radial piercing beamport. In purpose to determine the number of particles produced inside the reactor core, the calculation done for both 
neutron and gamma fluxes on each ring of reactor core configuration. While for the particle yields inside the radial piercing beamport, the calculation performed on the 0 -cm-range (base) and $92-\mathrm{cm}$ ranges from the reactor core wall.

\section{METHOD}

In the present work, the cross-section library ENDF/B (MCNPX 2.6.0) with MCNPX code was used to design and calculate the criticality of the reactor. The reactor simulated at the $100 \mathrm{~kW}$ of power and the simulation was performed in four steps, which include the design of the reactor construction, define the total particles and cycles use for simulation, execute the program and recording the neutron and gamma yields, and analysis the result. Each part of the reactor was designed and modelled, such as the reactor core, which contains of control rods, fuel element, lazy susan and reflector. The KRR uses concrete as main material for the outer wall.

Figure 1 describes the cross section of the KRR core configuration design that developed using visual editor (VISED). KCODE was used for criteria definitions of criticality calculation, which contain the information of the number of source histories per cycle and the total cycle chosen. Initial guess for $K_{\text {eff }}=1$ was also created in this criticality source code. This study had $10^{5}$ source histories per cycle and the total cycles of 1000, with a total of 60 cycles leftover. F2 tally, one of the calculation modes of MCNPX which has function to calculate beam flux which passed through the surface, were used for both gamma and neutron flux calculation. F2:n tally was used for neutron flux calculation command, while F2:p tally was used for gamma flux calculation command.

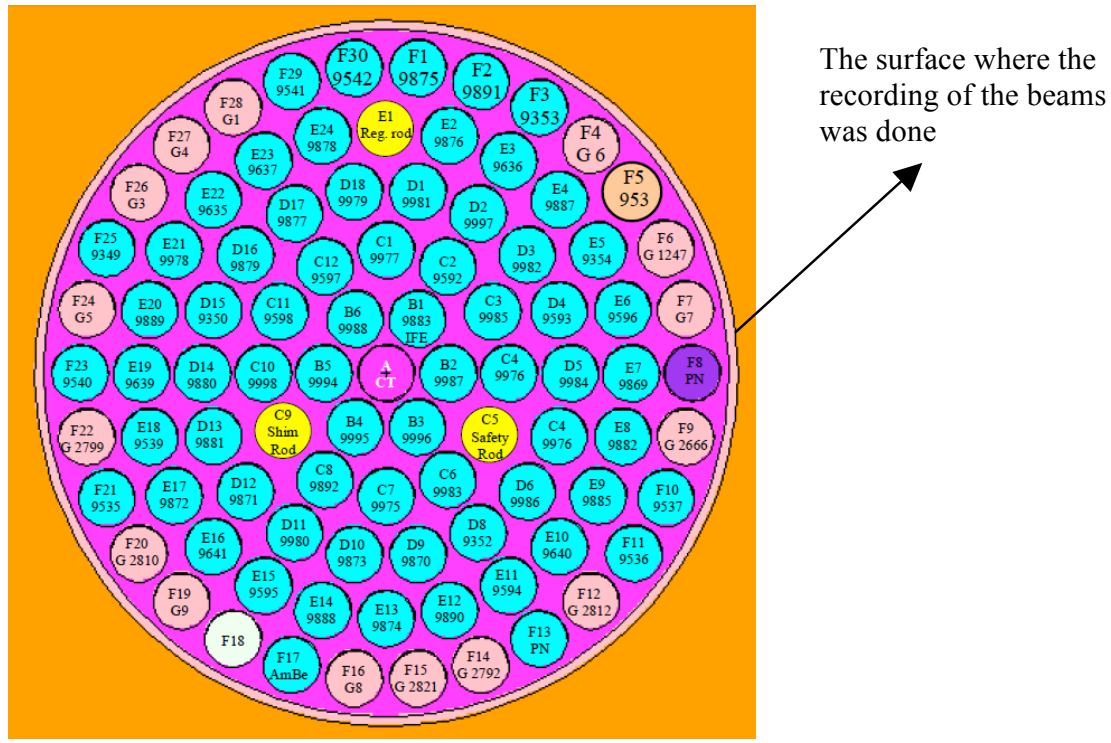

Fig. 1 Cross section of the fuel configuration of Kartini Research Reactor shown in visual editor (VISED)

In order to complement the recording purposes, SSW Card is also used as the command to run the recording in accordance with the beam direction. In this study, the recording of the beam was done on the 0 -cm-range (base of radial piercing beamport). This 0 -cm-range is placed on the surface 201 (the outer of the reactor core), with the beam direction left the cell 125 towards cell 148 (base of radial piercing beamport). In addition, the calculation of neutron and gamma flux also performed on each ring of KRR core configuration and also at the 92-cm-ranges from the base of radial piercing beamport. 


\section{RESULTS AND DISCUSSION}

The result of reactor criticality calculation is 1.00179 with an estimated standard deviation of 0.00007 , which means that the reactor condition is in a critical state. The measured $K_{\text {eff }}=$ $1.000+0.010$ is the actual condition of KRR [15], therefore, there is no change in neutron population over the time when its turn on and the chain reaction will be self-sustaining. The $K_{\text {eff }}$ resulted from the simulation that can be said as valid value. Figure 2 shows the neutron flux yields on each ring of the KRR core configuration. This data is served when the reactor is operated on 100 $\mathrm{kW}$ of power. The flux is presented in a spectrum energy group.

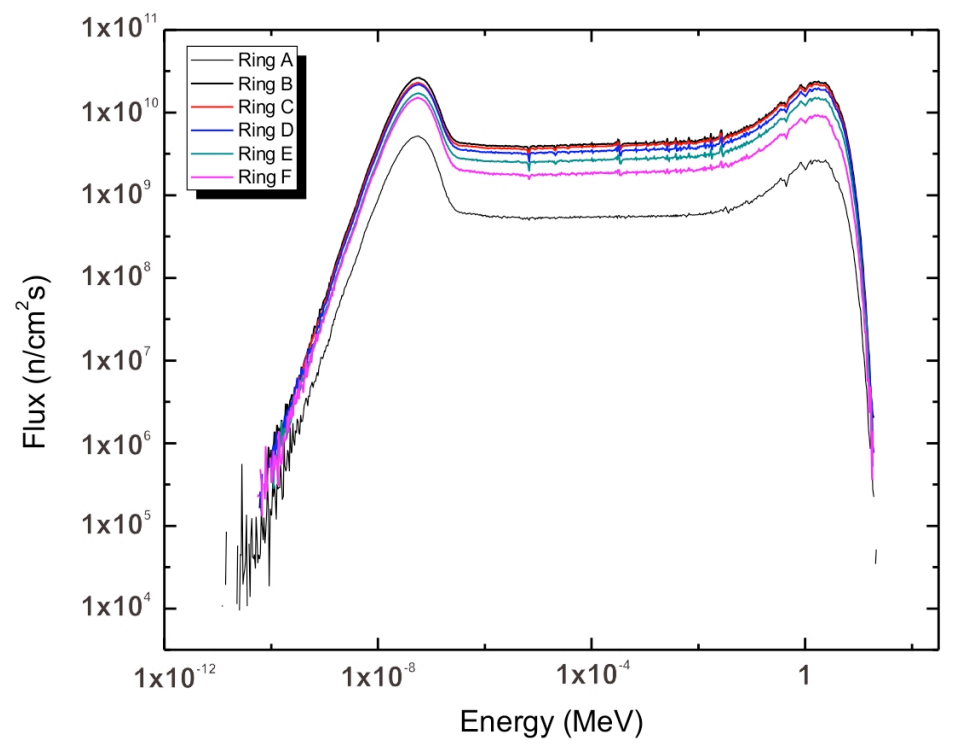

Fig. 2 The spectrum of neutron flux on each ring of Kartini Research Reactor

The neutron flux measured on ring $\mathrm{A}$ is the lowest compare to the other rings, which has a total neutron flux of $6.553 \times 10^{11} \mathrm{n} / \mathrm{cm}^{2} \mathrm{~s}$. This condition happened since there is no fuel placed on the fuel element of ring A. On ring B, the total neutron flux was $4.53 \times 10^{12} \mathrm{n} / \mathrm{cm}^{2} \mathrm{~s}$ and already decrease for each ring up to the ring F, that are $4.167 \times 10^{12} \mathrm{n} / \mathrm{cm}^{2} \mathrm{~s}$ for ring $\mathrm{C}, 3.751 \times 10^{12} \mathrm{n} / \mathrm{cm}^{2} \mathrm{~s}$ for ring $\mathrm{D}, 2.914 \times 10^{12} \mathrm{n} / \mathrm{cm}^{2} \mathrm{~s}$ for ring $\mathrm{E}$ and $3.107 \times 10^{12} \mathrm{n} / \mathrm{cm}^{2} \mathrm{~s}$ for ring F. Figure 3 shows the total neutron flux of each ring of the KRR core.

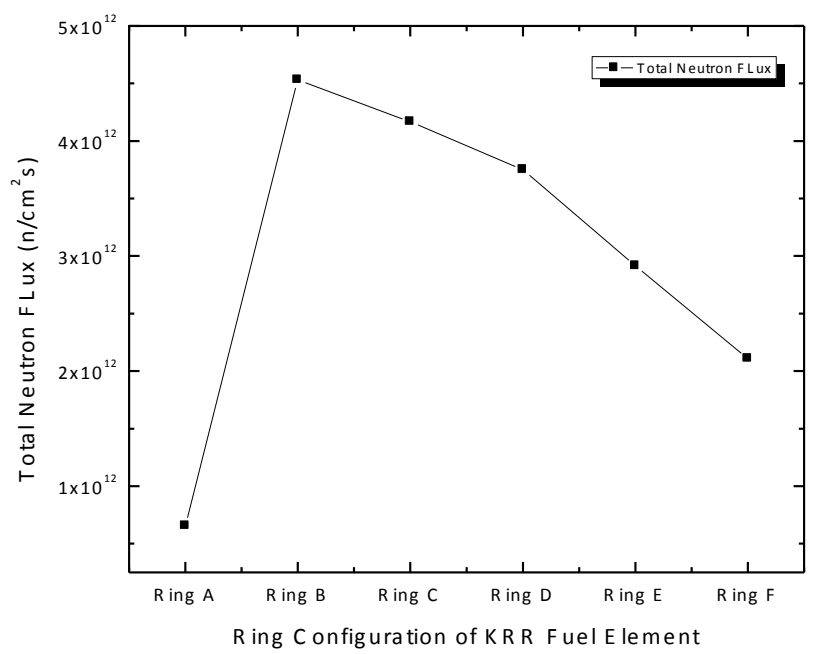

Fig. 3 The total neutron flux on each ring of Kartini Research Reactor Core 
The total neutron flux calculation on ring $\mathrm{B}, \mathrm{C}$ and $\mathrm{D}$ of the KRR core also have done using MCNP5 program and produced the total neutron flux of $1.52 \times 10^{12} \mathrm{n} / \mathrm{cm}^{2} \mathrm{~s}, 1.37 \times 10^{12} \mathrm{n} / \mathrm{cm}^{2} \mathrm{~s}$ and $1.27 \times 10^{12} \mathrm{n} / \mathrm{cm}^{2} \mathrm{~s}$, respectively [17]. The measurement data also served to compare the calculation data from the simulation with the measured data from the experiment. The neutron flux measured according to the experimental data on ring $B, C$ and $D$ are respectively $1.78 \times 10^{12} \mathrm{n} / \mathrm{cm}^{2} \mathrm{~s}, 1.56 \times 10^{12}$ $\mathrm{n} / \mathrm{cm}^{2} \mathrm{~s}$ and $1.14 \times 10^{12} \mathrm{n} / \mathrm{cm}^{2} \mathrm{~s}$ [17]. According to this comparation, there is a deviation value between the simulation results with the experiment. One of the factor causes of this deviation value is that the reactor geometry modelled is not as similar as the actual form. Simulation code based on Monte Carlo calculation serves the probability of particle interaction with the materials. Therefore, the different calculation results of this study give another probability of the total particle produced from the reaction inside the KRR core besides of the other study.

Other than the calculation of neutron particles, the calculation of gamma flux also done on each ring of the KRR core which served on Figure 4 as below.

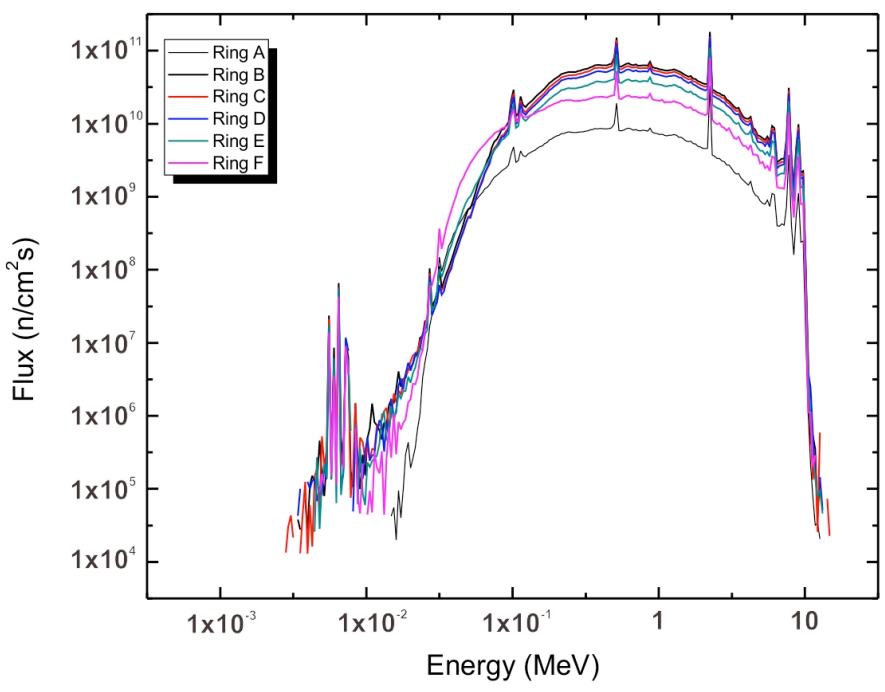

Fig. 4 The spectrum of gamma flux on each ring of Kartini Research Reactor

Gamma was also found in large amount inside the reactor core. The spectrum served on Figure 4 shows the total gamma flux calculated as a result of the simulation when the reactor is operated on $100 \mathrm{~kW}$ of power. While neutron was founded on wide energy ranges from thermal to fast, gamma beam only founded on fast energy ranges. The total gamma fluxes on ring A, B, C, D, $\mathrm{E}$ and $\mathrm{F}$ are respectively $6.956 \times 10^{11}$ particles $/ \mathrm{cm}^{2} \mathrm{~s}, 4.838 \times 10^{12}$ particles $/ \mathrm{cm}^{2} \mathrm{~s}, 4.398 \times 10^{12}$ particles $/ \mathrm{cm}^{2} \mathrm{~s}, 3.962 \times 10^{12}$ particles $/ \mathrm{cm}^{2} \mathrm{~s}, 2.953 \times 10^{12}$ particles $/ \mathrm{cm}^{2} \mathrm{~s}$ and $2.013 \times 10^{12}$ particles $/ \mathrm{cm}^{2} \mathrm{~s}$.

The calculation and recording of the particle yields were also done on the base of radial piercing beamport. The recording was conducted using the SSW card and reaches the calculation times of 1565.38 minutes. The recording aims to get the number of total particle yields on the reactor core wall, which directly connected to the radial piercing beamport, so that can be used for other simulations used KRR radial piercing beamport without performing the criticality calculation again, in purpose to reduce the calculation time. Figure 5 describes both neutron and gamma fluxes spectrum yield on the base of radial piercing beamport. 


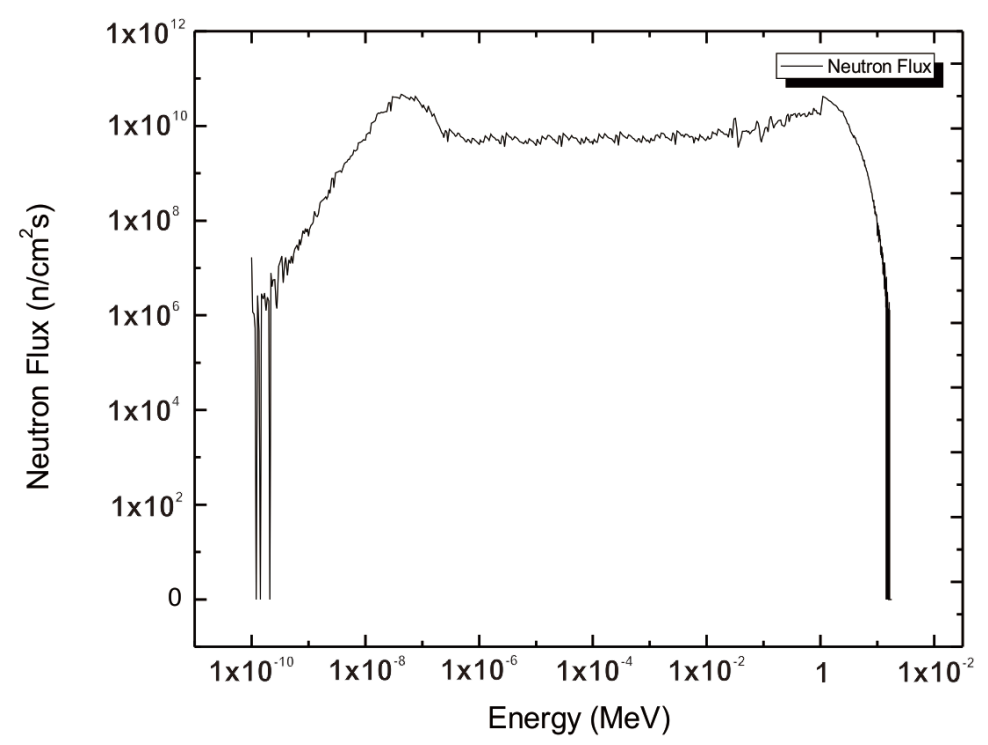

(a)

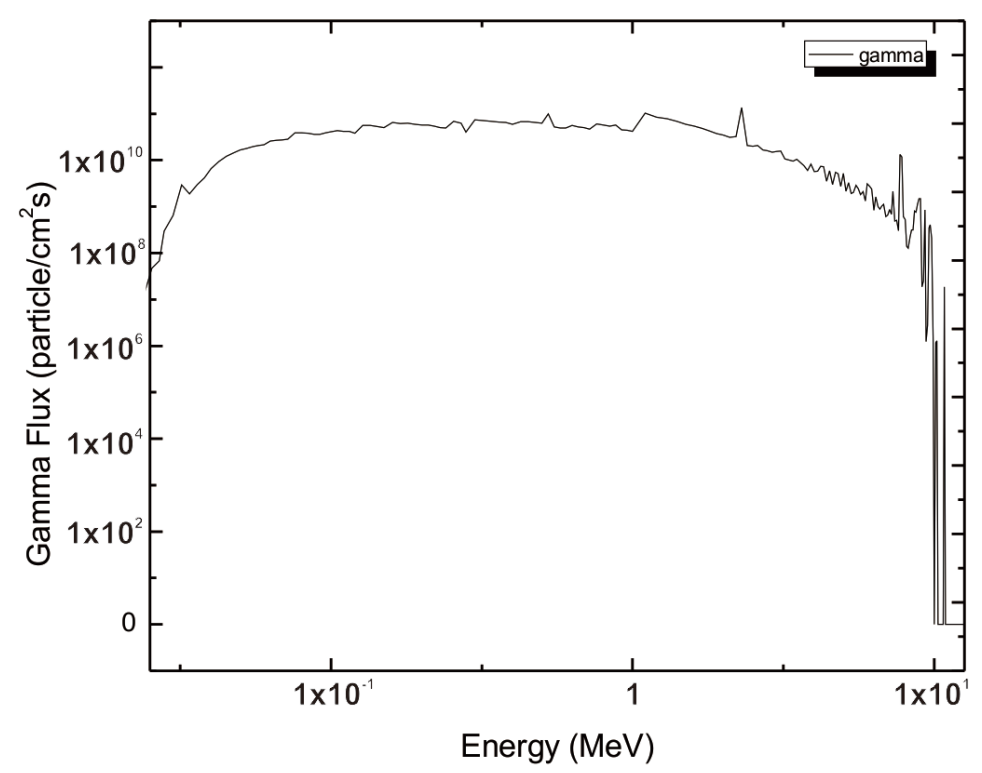

(b)

Fig. 5 Particle fluxes recorded on the base of radial piercing beamport of Kartini Research Reactor (a) neutron (b) gamma

In the context of BNCT, thermal energy is defined as energies below $0.5 \mathrm{eV}$, while epithermal energies are in the interval of $0.5 \mathrm{eV}-10 \mathrm{keV}$, and more than $10 \mathrm{keV}$ is defined as fast energy [1]. In this study, the thermal neutron fluxes frequently found at the energy range of $1.28 \times 10^{-8} \mathrm{MeV}$ to $1.9 \times 10^{-7} \mathrm{MeV}$, with the flux-peak of $4.678 \times 10^{10} \mathrm{n} / \mathrm{cm}^{2} \mathrm{~s}$ at $4.25 \times 10^{-8} \mathrm{MeV}-$ energy. In terms of epithermal neutron, it reaches a stable flux spectrum on the orde of $10^{9} \mathrm{n} / \mathrm{cm}^{2} \mathrm{~s}$. Frequently particle detected on $3 \times 10^{-3} \mathrm{MeV}$-beam energy, with the total flux of $7.784 \times 10^{9} \mathrm{n} / \mathrm{cm}^{2} \mathrm{~s}$. In addition, it is also seen on the spectrum that thermal neutron was found more often than the neutron with epithermal energy. One of the reasons is because KRR was designed for thermal chain reaction purposes. In contrast to fast reactors, the KRR utilizes Uranium-235 fuel, which indeed functions as a thermal neutron producer. The $\mathrm{U}^{235}$ fission reaction produces fast neutron on the reactor core. High purity hydrogen was utilized as a collimator that serves to slowing down the energy of neutron beams. Such fast neutron yields from the chain reaction in the reactor core will be collimated by high hydrogen so that neutrons which coming out of the core is in the form of 
thermal neutrons. In accordance with Figure 3, fast neutron spectrum gives a decrease number of neutron flux as a result of increasing particle energy. There are particles which are frequently risen and recorded clearly on the surface 201, as much as thermal neutrons. That is $1.1 \mathrm{MeV}$-neutron energy with the beam flux of $4.17 \times 10^{10} \mathrm{n} / \mathrm{cm}^{2} \mathrm{~s}$.

Widarto, et al [9] have measured neutron fluxes on the radial piercing beamport using Neutron Activation Analysis (NAA) method. On their study, they classified neutron particle in two different energy ranges, which are thermal neutron with energy less than $0.5 \mathrm{eV}$ and fast neutron with energy greater than $0.5 \mathrm{eV}$. Total neutron fluxes measured in the 0 -cm-range from reactor core is $(8.2 \pm 0.4) \times 10^{7} \mathrm{n} / \mathrm{cm}^{2} \mathrm{~s}$, with the thermal and fast neutron fluxes respectively are $(6.8 \pm 0.5) \times 10^{7}$ $\mathrm{n} / \mathrm{cm}^{2} \mathrm{~s}$ and $(1.43 \pm 0.07) \times 10^{7} \mathrm{n} / \mathrm{cm}^{2} \mathrm{~s}$ [9]. If it is compared with the simulation result of this study, there are different flux values. Several things can affect this different, such as: in the simulation, the reactor is assumed to operate in stable conditions, whereas the actual conditions are not; the efficiency of each reactor equipments which are not taken into the calculation of this simulation; the neutron detection method of this simulation is assumed also in stable condition, while the neutron detection using AAN method have several factor which can affect the calculation result, such as the relative error of the tool used in the measurement, the correction factor and the uncertainty value of neutron flux measurement [9].

Apart from producing neutron beams, gamma rays are also yield due to the neutron interaction inside the reactor core and it is described on Figure 3(b) above. The resulting gamma flux is still large as well, with the total gamma flux of $4.22 \times 10^{12}$ particles $/ \mathrm{cm}^{2} \mathrm{~s}$, since the beam which coming out from the core reactor has not filtrated and collimated. Therefore, it is necessary to have a material arranged in a radial piercing beamport which aims to filter the gamma generated in the process of reactor criticalization, so that the gamma comes out into the aperture is as low as possible.

Another spectrum on $92 \mathrm{~cm}$-ranges from the reactor core wall inside the radial piercing beamport has also been calculated. A range of $92 \mathrm{~cm}$ is the boundary between the inner beamport that has a 15-cm-diameter and the outer beamport which has a larger diameter of $19 \mathrm{~cm} \mathrm{[9].} \mathrm{Both}$ neutron and gamma spectrum are shown in Figure 6 below.

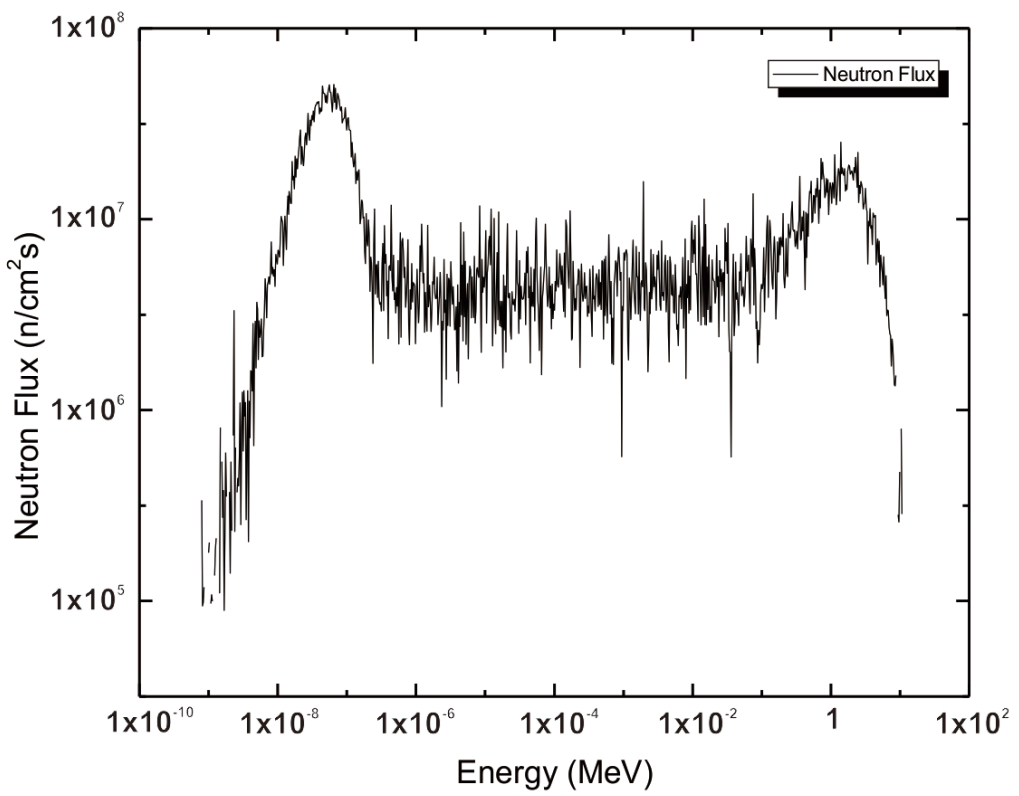

(a) 


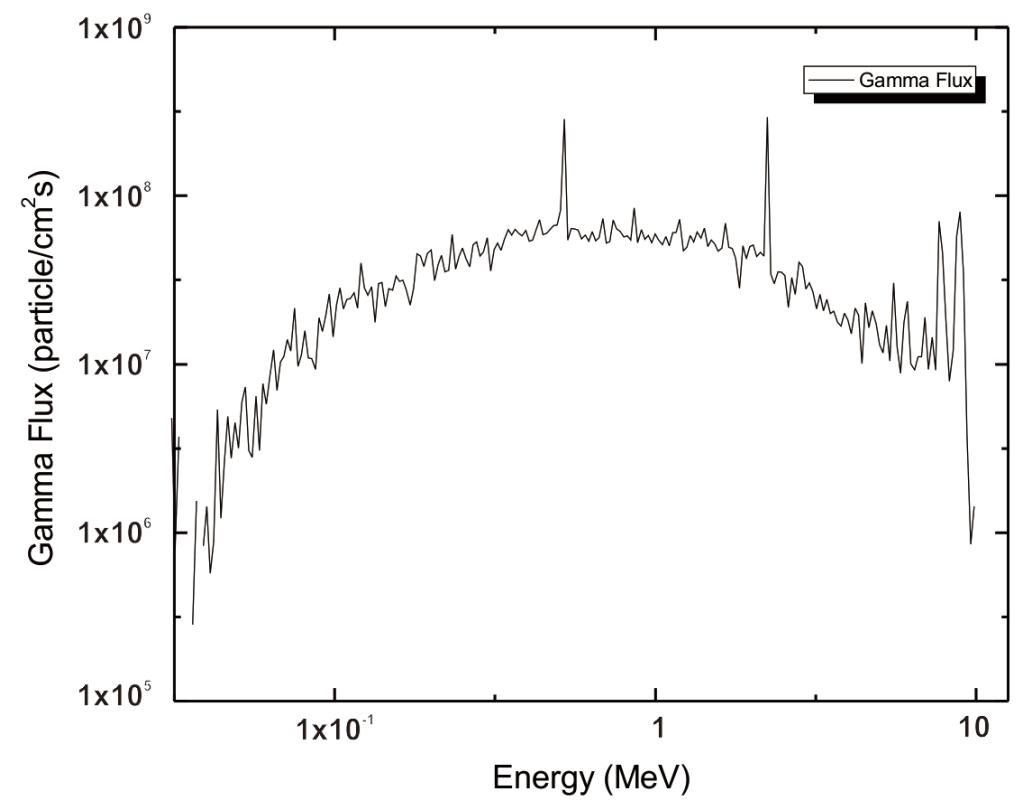

(b)

Fig. 6 Particles flux calculated on 92-cm-ranges from the base of radial piercing beamport of Kartini Research Reactor (a) neutron (b) gamma

Both neutron and gamma fluxes decrease from the 0-cm-range to the 92-cm-ranges inside the radial piercing beamport. On this ranges, the thermal neutron flux-peak reaches only $5.11 \times 10^{8}$ $\mathrm{n} / \mathrm{cm}^{2} \mathrm{~s}$, while for fast neutron reaches $2.55 \times 10^{7} \mathrm{n} / \mathrm{cm}^{2} \mathrm{~s}$ on $1.39 \mathrm{MeV}$-beam energy. The average of epithermal neutron flux also decreases up to $4.598 \times 10^{6} \mathrm{n} / \mathrm{cm}^{2} \mathrm{~s}$. The measurement on experiment also shows the decrease of the total neutron particle detected from $0 \mathrm{~cm}$ to $92-\mathrm{cm}$-ranges [9]. This condition is occurring because of the neutron particle interactions with the air inside the radial piercing beamport. In contrast with that, it is also seen in the neutron spectrum that there are several fast energies which have zero-flux value, such as in $1.01 \mathrm{MeV}, 1.09 \mathrm{MeV}, 1.15 \mathrm{MeV}, 1.18 \mathrm{MeV}$, 1.24 MeV, 1.29 MeV and 1.37 MeV. This condition means that there is no particle detected on the $92-\mathrm{cm}$-ranges inside the radial piercing beamport for that energy range. For gamma beam, it is also founded only on high energy with the total gamma flux of $8.241 \times 10^{8}$ particles $/ \mathrm{cm}^{2} \mathrm{~s}$.

The collimator design which begins from this range to the aperture of radial piercing beamport were ever performed by Arrozaqi, et al (2014) for BNCT purposes [17], but the neutron flux result only reaches $5 \times 10^{8} \mathrm{n} / \mathrm{cm}^{2} \mathrm{~s}^{1}$. This value is less appropriate to the regulation of International Atomic Energy Agency (IAEA). Some other neutron beam characterizations are also done on several reactors, which served for BNCT facility [7]. The result shows that several beam characteristics produced from 8 reactors are in accordance with the IAEA regulation for BNCT with the epithermal neutron flux greater than $1.0 \times 10^{9} \mathrm{n} / \mathrm{cm}^{2} \mathrm{~s}$ with the low number of fast neutron beam detected.

In concern with BNCT, IAEA as an international organization that seeks to promote the peaceful use of nuclear energy has a regulation for the BNCT beam criteria used. One of the beam parameters arranged is the epithermal neuton flux employed for BNCT, that is should be greater than $10^{9} \mathrm{n} / \mathrm{cm}^{2} \mathrm{~s}^{118}[18]$. Beams of $5 \times 10^{8} \mathrm{n} / \mathrm{cm}^{2} \mathrm{~s}^{1}$ are applicable but result in rather long irradiation time. The recording of neutron and gamma beams on the base and middle of radial piercing beamport has been done in this study. Moreover, the neutron particle yields on 92-cm-ranges is lowest than that of the IAEA parameter for BNCT. The fast neutron beam is also founded on high flux value and needed moderation so that it could be an epithermal neutron when coming out from the aperture. Therefore, other optimization design is needed to be further discussed so that the beam parameter out from the radial piercing beamport is appropriate to the IAEA regulation. 


\section{CONCLUSION}

Neutron and gamma beam were detected on the base of radial piercing beamport as a result of criticality calculation of KRR which prepare for BNCT in vivo/in vitro tests. The characteristics of neutron beams detected were $4.678 \times 10^{10} \mathrm{n} / \mathrm{cm}^{2}$ s-total flux for thermal neutron, with the epithermal neutron flux of $8.12 \times 10^{11} \mathrm{n} / \mathrm{cm}^{2} \mathrm{~s}$ and fast neutron total flux of $1.68 \times 10^{12} \mathrm{n} / \mathrm{cm}^{2} \mathrm{~s}$. The result shows the gamma rays present together with neutrons appear with the total flux of $4.22 \times 10^{12}$ particles $/ \mathrm{cm}^{2} \mathrm{~s}$. The neutron and gamma beam calculations are also performed on $92-\mathrm{cm}$-ranges from the reactor core wall inside the radial piercing beamport. The characteristic of beams detected were $5.11 \times 10^{8} \mathrm{n} / \mathrm{cm}^{2} \mathrm{~s}$ for thermal neutron flux, $4.598 \times 10^{6} \mathrm{n} / \mathrm{cm}^{2} \mathrm{~s}$ for epithermal neutron flux, $2.55 \times 10^{7} \mathrm{n} / \mathrm{cm}^{2} \mathrm{~s}$ for fast neutron flux and $8.214 \times 10^{10}$ particles $/ \mathrm{cm}^{2} \mathrm{~s}$ for gamma flux. According to the result, it can be concluded that there must be a study to choose a suitable material with the precise geometry which will be chosen for a collimation and a filter for both neutron and gamma so that the beam which coming out from the aperture are in accordance with the IAEA regulation for BNCT. The spectrum yield from this study can be used to define the source spectrum for BNCT simulation and optimization purposes used KRR as neutron source.

\section{ACKNOWLEDGEMENT}

The authors would like thank to PSTA BATAN which have given access to use the MCNPX program for simulation and also to all parties which have given much assistance so that this study could clearly done and could be useful for the BNCT researches. Please don't hesitate to contact the author on the email zailanrosila05@gmail.com if you have any questions.

\section{REFERENCES}

1. Cartelli D, Capoulat ME, Bergueiro J, Gagetti L, SuárezAnzorena M, delGrosso M.F., Baldo M, Castell W, Padulo J, SuárezSandín JC, Igarzabal M, Erhardt J, Mercuri D, Minsky DM, Valda AA, Debray ME, Somacal HR. Present status of accelerator-based BNCT : Focus on developments in Argentina. Appl Radiat Isot. 2015. 106:18-21

2. Kumada H, Kurihara T, Kobayashi H, Yoshioka M, Matsumoto H, Sugano T, Sakurai H, Sakae T, Matsumura A, Canepa N, Real N, Gun M, Herrera MS, Tacca H, Kreiner AJ. Development of Beryllium-Based Neutron Target System with Three-Layer Structure for Accelerator-Based Neutron Source for Boron Neutron Capture Therapy. Appl Radiat Isot. 2015

3. Juan A, Bergueiro J, Cartelli D, Baldo M, Castell W, Asoia JG, Padulo J, Sandín JCS, Igarzabal M, Erhardt J, Mercuri D, Valda AA, Minsky DM, Debray ME, Somacal HR, Capoulat ME, Herrera MS, del Grosso MF, Gagetti L, Anzorena MS, Canepa N, Real N, Gun M, Tacca H. Present status of Accelerator-Based BNCT. Reports Pract Oncol Radiother. 2014:7-13

4. Kasesaz Y, Bavarnegin E, Golshanian M, Khajeali A, Jarahi H. Progress in Nuclear Energy BNCT project at Tehran Research Reactor: Current and prospective plans. Progress in Nuclear Energy. 2016. 91:107-115

5. Bortolussi S, Protti N, Ferrari M, Postuma I, Fatemi S, Prata M, Ballarini F, Carante MP, Farias R, González SJ, Marrale M, Gallo S, Bartolotta A, Iacoviello G, Nigg D, Altieri S. Neutron flux and gamma dose measurement in the BNCT irradiation facility at the TRIGA reactor of the University of Pavia. Nucl Inst Methods Phys Res B. 2018. 414:113-120

6. Kawabata Y, Saito Y. Current activities of neutron imaging facilities in KUR ( Kyoto University research reactor ). Phys Procedia. 2013. 43:42-47

7. Anttila K, Kosunen A, Savolainen S. Measurement of free beam neutron spectra at eight BNCT facilities worldwide. 2004. 61:1021-1026 
8. Khaldun, M. Ibnu, Anang W.H. and Y. Sardjono. An Optimization Design of Collimator in the Thermal Column of Kartini Reactor for BNCT. Indonesian Journal of Physics and Nuclear Applications. 2017. 2(2):54-64

9. Widarto. Analisis dan Penentuan Distribusi Fluks Neutron Saluran Tembus Radial Untuk Pendayagunaan Reaktor Kartini. Ganendra. 2011. 5(1): 31-17

10. Galahom AA, Bashter II, Aziz M. Progress in Nuclear Energy Study the neutronic analysis and burnup for BWR fueled with hydride fuel using MCNPX code. Prog Nucl Energy. 2014. 77:65-71

11. Ibrahim A, Aziz M, El-kameesy SU, El-fiki SA, Galahom AA. Annals of Nuclear Energy Analysis of thorium fuel feasibility in large scale gas cooled fast reactor using MCNPX code. Ann Nucl Energy. 2018. 111:460-467

12. Erfaninia A, Hedayat A, Mirvakili SM. Progress in Nuclear Energy Neutronic study of a new generation of the small modular pressurized water reactor using Monte-Carlo simulation. Prog Nucl Energy. 2016. 93:218-230

13. Made MI, Dwiputra A, Harto AW, Sardjono Y. Shield Modelling of Boron Neutron Capture Therapy Facility with Kartini Reactor's Thermal Column as Neutron Source using Monte Carlo N Particle Extended Simulator. 2016

14. Priambodo G, Nugroho F, Palupi DS, Zailani R, Sardjono Y. Optimization of Biological Shield for Boron Neutron Capture. Tri Dasa Mega. 2017. 19(3):139-148

15. Arrozaqi, M. Ilma M., Kusminarto and Y. Sardjono. Preparation of Dosimetry of Boron Neutron Capture Therapy (BNCT) for In Vivo Test Planning System Using Monte Carlo N-Particle Extended (MCNPX) Software. Indonesian Journal of Physics and Nuclear Applications. 2016. 1(2):99-107

16. Widarto, Triatmoko IM, Wijaya GS. Quality Management System Program of in Vitro / in Vivo Test Facilityof Boron Neutron Capture Therapy at Kartini Research Reactor. Indonesian Journal of Physics and Nuclear Applications. 2016. 1(2):108-115

17. Arrozaqi, M. Ilma M., Y. Sardjono, Widiharto A. Perancangan Kolimator di Beamport Tembus Reaktor Kartini untuk Boron Neutron Capture Therapy. In: Pertemuan dan Presentasi Ilmiah - Penelitian Dasar Ilmu Pengetahuan dan Teknologi Nuklir PSTA BATAN. 2014. 163-178

18. IAEA. Current status of neutron capture therapy. Vienna, Austria: International Atomic Energy Agency. 2001 